\title{
UJI KINERJA DAN ANALISIS BIAYA MESIN PENCACAH PAKAN TERNAK (CHOPPER)
}

\section{(Performance Test and Cost Analysis of Chopper Machines)}

\author{
Novita Sari $^{\left.1^{*}\right)}$, Iqbal ${ }^{2)}$, dan Mahmud Achmad ${ }^{3)}$ \\ ${ }^{1)}$ Program Studi Teknik Pertanian, Universitas Hasanuddin, Makassar \\ ${ }^{2)}$ Program Studi Teknik Pertanian, Universitas Hasanuddin, Makassar \\ ${ }^{3)}$ Program Studi Teknik Pertanian, Universitas Hasanuddin, Makassar \\ *) Email korespondensi: Novita_sari91@yahoo.com
}

\begin{abstract}
ABSTRAK
Rumput gajah merupakan tanaman rumput-rumputan yang banyak dimanfaatkan pada bidang peternakan karena memiliki nutrisi yang dapat mempercepat pertumbuhan ternak. Mesin pencacah rumput gajah merupakan suatu mesin yang dapat membantu peternak dalam memenuhi kebutuhan pakan ternak. Penelitian ini dilaksanakan pada bulan Juni 2018 di Balai Besar Pelatihan Pertanian (BBPP) Batangkaluku Kabupaten Gowa, Sulawesi Selatan. Penelitian ini bertujuan untuk mengkaji kinerja mesin pencacah pakan ternak yang meliputi kapasitas mesin, persentase panjang cacahan bahan dan konsumsi bahan bakar serta menghitung biaya pokok pengoperasian alat tersebut. Hasil penelitian menunjukkan bahwa pada kecepatan putaran $740 \mathrm{rpm}$ diperoleh nilai rata rata kapasitas kerja mesin pencacah rumput gajah sebesar $121,4 \mathrm{~kg} / \mathrm{jam}$. Hasil persentase panjang cacahan rumput gajah $(<5 \mathrm{~cm})$ (W1) diperoleh nilai rata-rata sebesar 45,28 \%, Sedangkan hasil persentase panjang cacahan rumput gajah $(>5 \mathrm{~cm})(\mathrm{W} 2)$ diperoleh nilai rata-rata sebesar 54,62 \%. Untuk konsumsi bahan bakar pada mesin pencacah rumput gajah diperoleh nilai rata-rata sebanyak 1,24 $\ell / j a m$. Analisis biaya pokok terdiri dari biaya tetap dan biaya tidak tetap. Untuk biaya tetap mesin pencacah chopper model PC-700 sebesar Rp 4.272/jam, sedangkan biaya tidak tetap yaitu Rp 24.678/jam. Jadi total dari biaya pokok pengoperasian mesin pencacah chopper model PC-700 sebesar Rp 28.950/jam.
\end{abstract}

Kata Kunci: Mesin Pencacah, Rumput Gajah, Uji Kinerja, Analisis Biaya

\section{PENDAHULUAN}

\section{Latar Belakang}

Hijauan pakan ternak (forages) adalah pakan utama bagi kehidupan ternak. Salah satu hijauan pakan ternak adalah rumput gajah yang merupakan tanaman rumputrumputan. Rumput gajah banyak dimanfaatkan peternak karena memiliki nutrisi yang dapat mempercepat pertumbuhan ternak. Salah satu faktor utama yang diperhatikan adalah penyediaan pakan ternak sepanjang tahun secara kualitas dan kuantitas untuk memenuhi kebutuhan zat-zat makanan ternak dalam mempertahankan kelestarian hidup dan kebutuhan produksi.
Rumput gajah mulai dikenal dengan sebutan rumput napier atau rumput uganda yang memiliki umur panjang yang tumbuh tegak membentuk rumpun dan memiliki rhizoma-rhizoma pendek. Dapat tumbuh pada dataran rendah sampai pegunungan. Toleransi terhadap tanah yang cukup luas asalkan tidak mengalami genangan air. Responsif terhadap pemupukan nitrogen dan membutuhkan pemeliharaan yang cermat. Pemberian pupuk kandang dapat memperbaiki perkembangan akarnya (Rukmana, 2005).

Menurut Sanderson dan Paul (2008), rumput gajah adalah tanaman yang dapat 
tumbuh di daerah yang tanpa tambahan nutrisi, sehingga tanaman ini dapat memperbaiki kondisi tanah yang rusak akibat erosi, tanaman ini dapat hidup pada tanah kritis dimana tanaman lain relatif tidak dapat tumbuh.

Kebanyakan peternak skala kecil menggunakan pencacahan secara manual dengan sabit, parang ataupun alat pertanian konvensional lainnya. Pencacahan secara manual berbeda jauh dengan pencacahan menggunakan motor bakar, dimana pencacahan menggunakan motor bakar menghasilkan waktu yang relatif lebih cepat (Situmorang, 2012).

Mesin pencacah rumput adalah suatu alat berfungsi untuk mencacah atau merajang rumput yang akan dijadikan makanan ternak. Mesin ini bermanfaat untuk membantu kinerja peternak dalam menghasilkan pakan ternak yang akan membantu dalam proses pencernaan ternak dan persentase penyerapan nutrisinya lebih maksimal. Tanaman pakan yang akan dicacah terlebih dahulu dimasukkan melalui lubang pengumpan atau pemasukan kemudian dicacah dalam ruang pencacah. Sehingga bahan yang dicacah akan keluar berupa potongan-potongan hasil cacahan (Andasuryani, 2009).

Secara umum mesin pencacah rumput gajah terdiri dari motor yang berfungsi sebagai penggerak, sistem transmisi, casing, poros rangka dan pisau perajang. Pencacah ini digerakkan oleh motor penggerak. Sistem kerja motor penggerak dimulai dengan pulley bergerak, kemudian ditransmisikan ke sistem menggunakan sabuk transmisi untuk memutar poros. Pada poros terdapat enam pisau pencacah. Rumput gajah dimasukkan dalam hopper dengan pisau pencacah yang berputar sehingga dapat memotong rumput gajah. Mekanisme pemotongan pencacah rumput gajah (chopper) model PC-700 menggunakan pisau tebas, cara ini efektif untuk pemotongan dengan kecepatan tinggi yang mampu mengurangi waktu kerja sehingga lebih efisien.
Salah satu mesin pertanian yang digunakan untuk mencacah adalah mesin pencacah chopper Model PC-700. Mesin ini dibuat oleh Balai Besar Pelatihan Pertanian (BBPP) Batangkaluku Kabupaten Gowa yang digunakan dalam proses pencacahan pakan ternak. Tetapi belum digunakan dalam kegiatan pencacahan tradisional oleh peternak. Mesin ini memiliki umur ekonomis lebih dari lima tahun sehingga perlu dilakukan pengujian alat atau mesin pencacah dan menganalisis aspek-aspek dalam biaya pokok serta memberikan gambaran kelayakan mesin pencacah.

Analisis ekonomi digunakan untuk menentukan besarnya biaya yang harus dikeluarkan saat produksi menggunakan alat ini. Aplikasi prinsip-prinsip ekonomi teknik tidak hanya dibutuhkan dalam analisis kelayakan ekonomi proyek-proyek keteknikan tetapi juga dapat membantu dalam pengambilan keputusan untuk hal-hal yang bersifat pribadi yang akan memberikan dampak finansial yang akan datang (Salengke, 2012).

\section{Tujuan dan Kegunaan}

Tujuan dari penelitian ini adalah untuk mengkaji kinerja mesin pencacah pakan ternak (chopper) yang meliputi kapasitas mesin, persentase panjang cacahan bahan dan konsumsi bahan bakar serta menghitung biaya pokok pengoperasian alat tersebut.

Kegunaan dari penelitian ini adalah untuk memberikan informasi tentang kelayakan alat atau mesin yang digunaan peternak.

\section{METODE PENELITIAN}

\begin{abstract}
Alat
Alat yang digunakan pada penelitian ini yaitu Mesin Pencacah Model PC-700 (chopper), timbangan yang berfungsi untuk menimbang berat bahan awal (rumput gajah) yang akan dicacah, tachometer berfungsi untuk mengukur rotasi per menit (rpm) dari poros engkol mesin, stopwatch berfungsi mengukur lamanya waktu yang diperlukan mesin pencacah, mistar berfungsi untuk mengukur panjang daun rumput gajah, dan
\end{abstract}


gelas ukur berfungsi untuk mengukur volume bensin.

\section{Bahan}

Bahan yang digunakan pada penelitian ini yaitu tanaman rumput gajah dan bahan bakar bensin.

\section{Prosedur Penelitian}

Uji Kinerja dan Analisis Biaya Mesin Pencacah Pakan Ternak (Chopper) meliputi pengujian sebagai berikut :

\section{Uji unjuk kerja}

Uji terhadap kemampuan mesin pencacah (chopper) yang dioperasikan pada kondisi yang optimal.

\section{Pengukuran kapasitas mesin pencacah}

a) Menimbang bahan awal yang akan dicacah seberat $10 \mathrm{~kg}$ sesuai dengan kapasitas mesin pencacah.

b) Mengoperasikan mesin sampai putaran optimal, kemudian masukan bahan awal ke dalam ruang pencacah melalui lubang pengumpan atau pemasukan.

c) Setelah pengeluaran bahan yang dicacah stabil dari lubang pengeluaran,

d) Menampung bahan yang telah dicacah selama waktu yang ditentukan.

e) Menimbang dan mencatat bobot bahan cacahan tersebut.

f) Perlakuan ini dilakukan dalam 5 kali ulangan yang sama.

Kapasitas mesin pencacah dapat dihitung dengan rumus :

$$
C=\frac{W}{t_{1}} \times 3600
$$

Keterangan:

C : Kapasitas Mesin Pencacah (kg/jam)

$\mathrm{W}$ : Bobot bahan cacahan yang ditampung dari lubang keluaran selama waktu tertentu $(\mathrm{kg})$

$\mathrm{t}_{1}$ : Waktu yang ditentukan untuk menampung keluaran bahan cacahan melalui lubang keluaran (menit)

\section{Persentase Panjang cacahan bahan}

a) Mengambil sampel keluaran bahan cacahan sebanyak $100 \mathrm{~g}$, sebanyak 5 kali ulangan.

b) Memisahkan bahan cacahan dari sampel menjadi 2 (dua) bagian, bagian pertama yang panjangnya lebih pendek $50 \mathrm{~mm}$ dan bagian yang kedua yang panjangnya lebih panjang $50 \mathrm{~mm}$.

c) Menimbang kedua bagian sampel yang sudah dipisahkan.

Persentase panjang keluaran bahan cacahan dapat dihitung dengan rumus :

$$
P p k=\frac{W_{1}}{W_{1}+W_{2}} \times 100 \%
$$

Keterangan:

Ppk: Persentase panjang bahan keluaran hasil cacahan (\%)

$\mathrm{W}_{1}$ : Bobot keluaran bahan cacahan yang panjangnya kurang dari $50 \mathrm{~mm}(\mathrm{~g})$

$\mathrm{W}_{2}$ : Bobot keluaran bahan cacahan yang panjangnya lebih dari $50 \mathrm{~mm}(\mathrm{~g})$

\section{Konsumsi bahan bakar}

Konsumsi bahan bakar selama proses pencacahan dihitung dengan persamaan berikut:

Keterangan:

$$
F C=\frac{F V}{t_{2}}
$$

FC : Konsumsi bahan bakar ( $\ell /$ jam)

FV : Volume bahan bakar yang dipakai $(\ell)$.

$\mathrm{t}_{2}$ : Waktu beroperasinya motor penggerak (jam).

Analisis biaya pokok penggunaan alat mesin pertanian.

Biaya pokok penggunaan alat mesin pertanian ditentukan oleh dua faktor biaya yaitu biaya tetap (fixed cost) dan biaya tidak tetap (variable cost). Biaya pokok dihitung dengan persamaan:

Keterangan:

$$
C=\left(\sum B T+\sum B T T\right)
$$

C : Total biaya(total cost)

BT : Biaya tetap (fixed cost)

BTT : Biaya Tidak Tetap (variable cost)

\section{Biaya Tetap (Fixed Cost)}

a) Biaya penyusutan rata-rata

Biaya penyusutan rata-rata dapat dihitung dengan persamaan berikut :

Keterangan :

$$
D P=\frac{P-S}{N}
$$

DP : Biaya penyusutan pertahun (Rp/thn)

$\mathrm{P}$ : Harga beli alat mesin pertanian (Rp/unit)

$\mathrm{S}$ : Nilai akhir alat mesin pertanian (Rp/unit) 
$\mathrm{N}$ : Umur ekonomi alat mesin pertanian (tahun)

b) Biaya bunga modal

Biaya bunga modal dapat dihitung dengan persamaan berikut :

$$
I=\frac{i x(P-S) x(N+1)}{2 N}
$$

Keterangan :

I : Biaya bunga modal dan asuransi (Rp/tahun)

i : Tingkat bunga modal dan persen asuransi (\%)

$\mathrm{P}$ : Harga beli alat mesin pertanian (Rp/unit)

$\mathrm{S}$ : Nilai akhir alat mesin pertanian (Rp/unit)

$\mathrm{N}$ : Umur ekonomis alat mesin pertanian (Rp/unit)

c) Biaya pajak

Biaya pajak dapat dihitung dengan persamaan :

Keterangan :

$$
B P=P p x(P-S)
$$

BP : Biaya untuk pajak (Rp/thn)

$\mathrm{Pp}$ : Persentase biaya pajak (2\% atau 0.02 )

$\mathrm{P}$ : Harga beli alat mesin pertanian (Rp/unit)

$\mathrm{S}$ : Nilai akhir alat mesin pertanian (Rp/unit)

d) Biaya garasi atau gudang

Biaya garasi atau bangunan untuk alat dan mesin pertanian dapat dihitung dengan menggunakan persamaan :

Keterangan :

$$
B g=P g x(P-S)
$$

$\mathrm{Bg}$ : Biaya garasi atau gudang (Rp/thn)

$\mathrm{Pg}$ : Persen biaya garasi (1\% atau 0.01 )

$\mathrm{P}$ : Harga beli alat mesin pertanian (Rp/unit)

$\mathrm{S}$ : Nilai akhir alat mesin pertanian (Rp/unit)

Biaya Tetap = Biaya penyusutan + Biaya bunga modal + Biaya pajak + Biaya Garasi

\section{Biaya Tidak Tetap (Variable Cost)}

a) Biaya bahan bakar

Biaya bahan bakar dapat dihitung dengan persamaan:

Keterangan :
$\mathrm{Bb}$ : Biaya bahan bakar (Rp/jam)

$\mathrm{Kb}$ : Konsumsi bahan bakar (liter/jam)

$\mathrm{Hb}$ : Harga bahan bakar (Rp/liter)

b) Biaya Pelumas

Biaya pelumas (Oli dan gemuk) dari alat mesin pertanian dapat dihitung dengan persamaan:

Keterangan :

$$
B p=K p \times H p
$$

$\mathrm{Bb}$ : Biaya pelumasan (Rp/jam)

$\mathrm{Kp}$ : Konsumsi pelumas (liter/jam)

$\mathrm{Hp}$ : Harga pelumas (Rp/liter)

c) Biaya Pemelihara

Biaya pemeliharaan atau biaya perawatan dapat dihitung dengan persamaan sebagai berikut :

$$
B r=\frac{1,2 \%}{100 \text { jam }} x(P-S)
$$

Keterangan :

$\mathrm{Br}$ : Biaya pemeliharaan (Rp/jam)

$\mathrm{P}$ : Harga beli alat mesin pertanian (Rp/unit)

$\mathrm{S}$ : Nilai akhir alat mesin pertanian (Rp/unit)

d). Biaya Operator

Biaya operator dapat dihitung dengan persamaan :

$$
\text { Bo }=U x \frac{J k}{1 \text { Hari }} x J o
$$

Keterangan :

Bo : Biaya operator alat mesin pertanian (Rp/jam)

$\mathrm{U}$ : Upah operator per hari (Rp/hari)

$\mathrm{Jk}$ : Jam kerja per hari (jam/hari)

Jo : Jumlah operator (jam/hari)

Biaya Tidak Tetap = Biaya Bahan Bakar + Biaya Pelumas + Biaya Pemeliharaan + Biaya Operator

\section{HASIL DAN PEMBAHASAN}

\section{Kapasitas Mesin Pencacah}

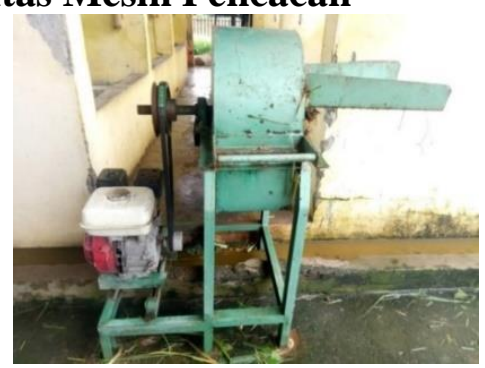

Gambar 1. Mesin Pencacah 
Spesifikasi Mesin Pencacah Rumput Model PC-700, Antara lain :

- Kapasitas : $600-700 \mathrm{Kg} / \mathrm{jam}$

- Model : PC-700

- Dimensi : $120 \mathrm{~cm}$ x $70 \mathrm{~cm}$ x $120 \mathrm{~cm}$

- Penggerak :6-7 Hp

- Jumlah pisau : 6 buah

- Umur alat :5 thn

Pengukuran kapasitas kerja mesin pencacah yaitu dengan cara membagi bobot bahan cacahan dengan waktu keluaran bahan cacahan. Menurut Hidayat (2006), Kapasitas alat mesin pencacah pakan ternak sangat ditentukan oleh besarnya putaran (rpm) piringan pencacah dan piringan pembawa. Kapasitasnya akan berbanding lurus dengan meningkatnya putaran kedua piringan, namun mutu hasil cacahannya belum memenuhi persyaratan yang diinginkan karena masih banyak yang tidak tercacah. Piringan pembawa berfungsi untuk mengait pakan yang akan dipotong, jika rpm-nya terlalu tinggi maka bahan akan cepat keluar dan tidak terpotong, sebaliknya jika rpm piringan pembawa terlalu rendah, hasil cacahannya cukup baik akan tetapi kapasitasnya menurun. Jenis tanaman yang dicacah yaitu tanaman rumput gajah.

Penelitian dilakukan sebanyak 5 kali ulangan yang sama dimana setiap ulangan masing-masing menggunakan $10 \mathrm{~kg}$ rumput gajah dengan kecepatan putaran mesin 740 rpm.

Tabel 1. Kapasitas Mesin Pencacah Pada Bobot Bahan Awal 10 kg dengan Kecepatan Putar 740 rpm

\begin{tabular}{cccc}
\hline Sampel & $\begin{array}{c}\text { Bobot } \\
\text { cacahan }\end{array}$ & $\begin{array}{c}\text { Waktu } \\
\text { cacahan } \\
\text { (menit) }\end{array}$ & $\begin{array}{c}\text { Kapasitas } \\
\text { Mesin } \\
\text { Pencacah } \\
\text { (kg/jam) }\end{array}$ \\
\hline 1 & 9,5 & 4,4 & 129,6 \\
2 & 9,7 & 5,1 & 114,1 \\
3 & 9,8 & 5,5 & 106,9 \\
4 & 9,4 & 4,3 & 131,2 \\
5 & 9,6 & 4,6 & 125,2 \\
\hline $\begin{array}{c}\text { Rata- } \\
\text { rata }\end{array}$ & $\mathbf{9 , 6}$ & $\mathbf{4 , 8}$ & $\mathbf{1 2 1 , 4}$ \\
\hline
\end{tabular}

Tabel 1 bobot bahan awal (rumput gajah) $10 \mathrm{~kg}$ menghasilkan rata-rata bobot bahan cacahan sebanyak 9,6 kg. Besar kapasitas mesin ditentukan oleh banyaknya bahan yang masuk mesin pencacah. Sesuai dengan hasil penelitian Hidayat (2006) bahwa, banyaknya kapasitas cacahan bahan dipengaruhi oleh kecepatan putar yang tinggi, bobot cacahan dengan bahan awal yang sama dipengaruhi oleh kekerasan bahan dan bahan cacahan yang menempel pada badan mesin pencacah (chopper).

Hasil pencacahan menunjukkan waktu rata-rata yang dibutuhkan untuk mencacah rumput gajah sebesar 4,8 menit. Dari hasil pengujian yang dilakukan diperoleh kapasitas efektif rata-rata mesin pencacah rumput gajah (chopper) sebesar 121,4 $\mathrm{kg} / \mathrm{jam}$. Sesuai dengan persyaratan kerja mesin pencacah tanaman rumput gajah pada SNI 7580:2013 bahwa kapasitas efektif alat dibagi menjadi 3 kelas yaitu kelas A dengan kapasitas <600 kg/jam, kelas B dengan kapasitas 600-1500 kg/jam dan kelas C dengan kapasitas $>1500 \mathrm{~kg} / \mathrm{jam}$. Sehingga kapasitas pencacah pakan ternak termasuk kelas A.

\section{Persentase Panjang Cacahan Bahan}

Hasil panjang cacahan rumput gajah didapatkan data bahwa dari 5 pengulangan menggunakan kecepatan putar yang sama yaitu $740 \mathrm{rpm}$. Sampel persentase panjang cacahan rumput gajah yang digunakan sebanyak 100 g kemudian diambil secara acak dan diukur panjangnya.

Hasil keluaran cacahan rumput gajah dengan ukuran panjangnya lebih dari $50 \mathrm{~mm}$ $(>5 \mathrm{~cm})$ diperoleh rata-rata sebesar 52,48\% $\left(\mathrm{W}_{1}\right)$. Sedangkan hasil cacahan dengan ukuran panjangnya kurang dari $50 \mathrm{~mm}(<5$ $\mathrm{cm})$ diperoleh rata-rata keluaran cacahan rumput gajah sebesar $43,54 \%\left(\mathrm{~W}_{2}\right)$

Tabel 2. Persentase Panjang Cacahan Bahan Pada Kecepatan Putar 740 rpm

\begin{tabular}{ccccc}
\hline Sampel & $\begin{array}{c}\mathbf{W}_{\mathbf{1}} \\
(\mathbf{g})\end{array}$ & $\begin{array}{c}\mathbf{W}_{\mathbf{2}} \\
(\mathbf{g})\end{array}$ & $\begin{array}{c}\mathbf{W}_{\mathbf{1}} \\
(\mathbf{\%})\end{array}$ & $\begin{array}{c}\mathbf{W}_{\mathbf{2}} \\
(\mathbf{\%})\end{array}$ \\
\hline 1 & 41,9 & 53,9 & 43,7 & 56,2 \\
2 & 44,7 & 50,9 & 46,7 & 53,2 \\
3 & 43,9 & 52,2 & 45,6 & 54,3 \\
4 & 43,5 & 53,6 & 44,7 & 55,2 \\
5 & 43,7 & 51,8 & 45,7 & 54,2 \\
\hline Rata-rata & $\mathbf{4 3 , 5 4}$ & $\mathbf{5 2 , 4 8}$ & $\mathbf{4 5 , 2 8}$ & $\mathbf{5 4 , 6 2}$ \\
\hline
\end{tabular}


Keterangan :

$\mathrm{W}_{1}=$ Cacahan bahan dengan panjang kurang dari $50 \mathrm{~mm}$

$\mathrm{W}_{2}=$ Cacahan bahan dengan panjang lebih dari $50 \mathrm{~mm}$

Tabel 2 pengujian persentase panjang cacahan rumput gajah (chopper) menggunakan kecepatan putar $740 \mathrm{rpm}$. Hasil persentase panjang cacahan bahan ukuran kurang dari $50 \mathrm{~mm}\left(\mathrm{~W}_{1}\right)$ diperoleh rata-rata sebesar 45,28\%, sedangkan ratarata persentase panjang cacahan bahan ukuran lebih dari $50 \mathrm{~mm}\left(\mathrm{~W}_{2}\right)$ sebesar $54,62 \%$, cara untuk mendapatkan hasilnya dapat dilihat pada persamaan 2. Untuk ukuran hasil cacahan yang baik adalah 2-5 cm sesuai dengan SNI 7785.1:2003 tentang persyaratan hasil cacahan mesin pencacah hijauan pakan. Ukuran hasil cacahan $2-5 \mathrm{~cm}$ dikatakan baik karena dapat mempermudah ternak mengkonsumsi pakan dan memudahkan proses pencernaan ternak. Menurut Situmorang (2012) bahwa pencacahan secara manual berbeda jauh dengan pencacahan menggunakan motor bakar, dimana pencacahannya menghasilkan waktu lebih yang relatif cepat.

\section{Konsumsi Bahan Bakar}

Konsumsi bahan bakar dapat dihitung dengan cara membagi antara volume bahan bakar dengan waktu mesin beroperasi. Penggunaan bahan bakar diperoleh dengan mengukur konsumsi bahan bakar dengan melakukan pengisian tangki bahan bakar sebelum mesin beroperasi. Kemudian mengisi kembali tangki setelah proses mencacah selesai. Banyaknya bahan bakar yang diisi pada tangki merupakan pemakaian bahan bakar selama proses pencacahan.

Tabel 3. Konsumsi Bahan Bakar Pada Kecepatan Putar 740 rpm

\begin{tabular}{|c|c|c|c|}
\hline Sampel & $\begin{array}{c}\text { Waktu } \\
\text { cacahan } \\
\text { (detik) }\end{array}$ & $\begin{array}{c}\text { Konsumsi } \\
\text { bahan } \\
\text { bakar } \\
\text { (ml) }\end{array}$ & $\begin{array}{c}\text { Konsumsi } \\
\text { bahan bakar } \\
(\ell / \text { jam })\end{array}$ \\
\hline 1 & 264 & 90 & 1,22 \\
\hline 2 & 306 & 110 & 1,29 \\
\hline 3 & 330 & 120 & 1,31 \\
\hline 4 & 258 & 80 & 1,11 \\
\hline 5 & 276 & 100 & 1,3 \\
\hline
\end{tabular}

\begin{tabular}{cccc}
\hline Sampel & $\begin{array}{c}\text { Waktu } \\
\text { cacahan } \\
(\text { detik })\end{array}$ & $\begin{array}{c}\text { Konsumsi } \\
\text { bahan } \\
\text { bakar } \\
(\mathbf{m l})\end{array}$ & $\begin{array}{c}\text { Konsumsi } \\
\text { bahan bakar } \\
(\ell / \text { jam })\end{array}$ \\
\hline $\begin{array}{c}\text { Rata- } \\
\text { rata }\end{array}$ & 287 & 100 & 1,24 \\
\hline
\end{tabular}

Tabel 3 pengujian konsumsi bahan bakar dengan 5 kali pengulangan menggunakan kecepatan putar yang sama yaitu $740 \mathrm{rpm}$. Pernyataan ini sesuai dengan hasil penelitian Hidayat (2006) bahwa, besarnya daya yang digunakan dipengaruhi oleh beban yang dikenakan pada piringan pembawa dan pemotong. Pada volume bahan yang sama akan memberi dampak yang sama terhadap daya yang digunakan.

Hasil bahan bakar yang digunakan selama pencacahan diperoleh rata-rata sebesar 1,24 $\ell /$ jam dengan lama pencacahan 287 detik atau 4,8 menit. Berdasarkan SNI 7580:2013 persyaratan untuk kerja mesin pencacah (chopper)untuk konsumsi bahan bakar dikelompokkan menjadi 3 kelas, yaitu kelas A dengan konsumsi <2 l/jam, kelas B dengan konsumsi 2-3 $\ell /$ jam dan kelas $\mathrm{C}$ dengan konsumsi $>3 \quad \ell / j a m$. Sehingga konsumsi bahan bakar pada mesin pencacah rumput gajah (chopper) dikelompokkan pada kelas A.

\section{Analisis Ekonomi (Biaya Pokok)}

Aplikasi prinsip-prinsip ekonomi teknik tidak hanya dibutuhkan dalam analisis kelayakan ekonomi proyek-proyek keteknikan tetapi juga dapat membantu dalam pengambilan keputusan untuk hal-hal yang bersifat pribadi yang akan memberikan dampak finansial yang akan datang. Proses produksi bertujuan untuk mengubah bahan baku menjadi produk jadi melalui serangkaian proses sehingga memperoleh nilai tambah.

\section{Biaya Tetap (Fixed Cost)}

Biaya-biaya yang termasuk dalam biaya tetap (fixed cost) meliputi biaya penyusutan, biaya bunga modal dan asuransi, biaya pajak dan biaya garasi atau gudang. Untuk lebih jelasnya mengenai perincian biaya tetap (fixed cost), dapat dilihat pada Tabel 4 . 
Tabel 4. Perincian Biaya Tetap (Fixed Cost) Pada Mesin Pencacah Rumput Model PC700 di BBPP Batangkaluku.

\begin{tabular}{lcr}
\hline \multicolumn{1}{c}{ Biaya Tetap } & Satuan & \multicolumn{1}{c}{ Biaya } \\
\hline Penyusutan Rata-rata & (Rp/tahun) & 1.380 .000 \\
Bunga Modal & (Rp/tahun) & 463.680 \\
Pajak & $($ Rp/tahun $)$ & 138.000 \\
Gudang & $($ Rp/tahun) & 69.000 \\
\hline Total biaya tetap (A) & (Rp/tahun) & $\mathbf{2 . 0 5 0 . 6 8 0}$ \\
& $($ Rp/Hari) & $\mathbf{3 4 . 1 7 8}$ \\
& $($ Rp/Jam) & $\mathbf{4 . 2 7 2}$ \\
\hline
\end{tabular}

Tabel 4 menunjukkan bahwa biaya tetap (fixed cost) pada mesin pencacah Model PC-700 dengan kapasitas kerja per tahun adalah sebesar Rp 2.050.680. Yang terdiri dari biaya penyusutan rata-rata sebesar Rp 1.380.000/tahun, biaya bunga modal sebesar $\mathrm{Rp} \mathrm{463.680/tahun,} \mathrm{biaya}$ pajak sebesar Rp 138.000/tahun dan biaya gudang sebesar Rp. 69.000/tahun.

\section{Biaya Tidak Tetap (Variable Cost)}

Biaya-biaya yang termasuk dalam biaya tetap (variable cost) meliputi biaya bahan bakar, biaya pelumas, biaya pemeliharaan dan biaya operator. Untuk lebih jelasnya mengenai perincian biaya tidak tetap dapat dilihat pada Tabel 5.

Tabel 5. Perincian Biaya Tidak Tetap (Variable Cost) Pada Mesin Pencacah Rumput Model PC-700 di BBPP Batangkaluku.

\begin{tabular}{lcr}
\hline \multicolumn{1}{c}{ Biaya Tidak Tetap } & Satuan & \multicolumn{1}{c}{ Biaya } \\
\hline Biaya BBM & $($ Rp/jam $)$ & 6.450 \\
Biaya operator & $($ Rp/jam $)$ & 17.000 \\
Biaya Pelumas & $($ Rp/jam $)$ & 400 \\
Biaya Pemeliharaan & $($ Rp/jam $)$ & 828 \\
\hline $\begin{array}{l}\text { Total Biaya Tidak } \\
\text { tetap (B) }\end{array}$ & (Rp/jam) & $\mathbf{2 4 . 6 7 8}$ \\
\hline
\end{tabular}

Tabel 5 menunjukkan bahwa biaya tidak tetap (variable cost) pada mesin pencacah Model PC-700 dengan kapasitas kerja per jam sebesar Rp 24.678. Yang terdiri dari biaya bahan bakar sebesar Rp 6.450/jam, bahan bakar yang digunakan adalah bensin, biaya operator sebesar Rp 17.000/jam, biaya pelumas sebesar $\mathrm{Rp}$ 400/jam, dan biaya pemeliharaan sebesar 828/jam.
Jurnal AgriTechno. Vol. 11 (2): 113-120

https://doi.org/ 10.20956/at.v1 1i2.115

Dari analisis ekonomi biaya pokok berupa biaya pokok terdiri dari biaya tetap dan biaya tidak tetap. Total dari biaya pokok pengoperasian alat dengan kapasitas kerja sebesar Rp 28.950/jam.

\section{KESIMPULAN}

Berdasarkan hasil penelitian yang telah dilakukan, dapat disimpulkan :

1. Rata-rata kapasitas kerja mesin pencacah rumput gajah model PC-700 (Chopper) yaitu $121,4 \mathrm{~kg} / \mathrm{jam}$.

2. Persentase panjang cacahan rumput gajah dengan ukuran kurang dari $50 \mathrm{~mm}$ $(<5 \mathrm{~cm})\left(\mathrm{W}_{1}\right)$ diperoleh rata-rata sebesar $45,28 \%$, sedangkan persentase panjang cacahan rumput gajah dengan ukuran lebih dari $50 \mathrm{~mm}(>5 \mathrm{~cm})\left(\mathrm{W}_{2}\right)$ diperoleh rata-rata sebesar 54,62\%. Untuk ukuran hasil cacahan yang baik adalah $2-5 \mathrm{~cm}$ sesuai dengan SNI 7785.1:2003 tentang persyaratan hasil cacahan mesin pencacah hijauan pakan.

3. Rata-rata konsumsi bahan bakar yang digunakan pencacah rumput gajah model PC-700 (Chopper) yaitu 1,24 l/jam.

4. Biaya pokok pengoperasian alat sebesar Rp. 28.950/jam.

5. Mesin pencacah pakan ternak (Chopper) Model PC-700 dari segi ekonomi atau finansial belum layak untuk diusahakan

\section{DAFTAR PUSTAKA}

Andasuryani, 2009. Membangun Mesin Pencacah Rumput Gajah Untuk Peningkatan Konsumsi Pakan Ternak Sapi. Artikel Ilmiah Pelaksanaan Program Pengabdian Tahun 2009.

Dewan Standar Nasional, 2010. SNI 75802010. Mesin Pencacah Bahan Pupuk Organik, Syarat Mutu dan Metode Uji.

Hidayat, M., Harjono, Marsudi, Andri Gunanto dkk. 2006. Evaluasi Kinerja Teknik Mesin Pencacah Hijauan Pakan Ternak. Jurnal Teknik Pertanian. Balai Besar Pengembangan Mekanisasi Pertanian. Vol. IV, No.2, 2006: 61-64. 
Rukmana, R, 2005. Rumput Gajah Makanan Ternak. Yogyakarta.

Salengke, 2012. Ekonomi Teknik. Universitas Hasanuddin: Makassar

Sanderson, M.A. and R.A, Paul, 2008. Perennial Forages As Second Generation Bioenergy Crops. International Journal of Molecular Science. 